\title{
THE USE OF KNOWLEDGE MAP MODEL IN CONSTRUCTION INDUSTRY
}

\author{
H. Ping Tserng ${ }^{1}$, Samuel Yen-Liang Yin ${ }^{2}$, Meng-Hsueh Lee ${ }^{3}$ \\ ${ }^{1}$ Department of Civil Engineering, National Taiwan University, 1 Roosevelt Rd., Sec. 4, Taipei, Taiwan \\ ${ }^{2}$ Department of Civil Engineering, National Taiwan Univ., 1 Roosevelt Rd., Sec. 4, Taipei, Taiwan; \\ CEO and Chief R\&D Officer, Ruentex Group, 14F., No. 308, Section 2, Bade Road, Taipei, Taiwan \\ ${ }^{3}$ Div. of Construction Engineering and Management, Department of Civil Engineering, \\ National Taiwan University, 1 Roosevelt Rd., Sec. 4, Taipei, Taiwan \\ E-mails: ${ }^{1}$ hptserng@ntu.edu.tw; ${ }^{2}$ Samuel@mail.ruentex.com.tw; ${ }^{3}$ d92521016@ntu.edu.tw
}

Received 25 Dec. 2008; accepted 18 Mar. 2010

\begin{abstract}
The construction industry consists of many unstructured documents, which accumulate a large volume of tacit knowledge. In the general domain, a Knowledge Map can illustrate connections of knowledge and transfer tacit knowledge to explicit knowledge, but this is unsuitable on specific domain such as construction industry. This research generalized existing mapping rules to be applied to general and specific domain; and presented a novel and practical model for building knowledge map, named Knowledge Map Model (KMM). This model comprised of five procedures, including identifying problems, discussing with experts and users, establishing the classification structure, establishing the document base, and deciding the display model. Furthermore, this research establishes Knowledge Map Model System (KMMS) as a major tool to improve the knowledge map reused and shared among the practical process. Finally, this research validated the KMM in a real project of bridge maintenance.
\end{abstract}

Keywords: knowledge map, construction industry, information technology.

\section{Introduction}

The construction industry consists of many unstructured documents, which accumulate volumes of tacit engineering experiences and domain knowledge (Gabrielaitis and Baušys 2006; Lin 2008; Lin et al. 2006; Woo et al. 2004). Tacit knowledge is difficult to express in formal language, therefore explicit knowledge is easy to codify and expressed in formal language (Tserng and Lin 2004). Transferring the tacit knowledge to explicit knowledge is usually accomplished by document analysis. Document analysis is not a new technology. In academic field of information technology, primary research dealing with document analysis usually focused on the generic field and enhancing algorithm efficiency of Information Retrieval and Automated Text Categorization. If specific field uses information technology come from generic field, it is necessary to modify the algorithm for specific requirements. Besides, several techniques can be employed to analyze relationship among documents. One example is the approach of using text information integrated methodology to improve the integration of text documents and information system, which based on text mining. Another approach uses the metadata model to improve manual medium which integrated architectural elements, construction process and project management by architect specification (Hajjar and AbouRizk 2000). Additionally, general available commercial software can handle document management and knowledge classification in explicit knowledge (Lin et al. 2006). In construction industry, information technology can facilitate knowledge transferring and assist experts to search, communicate and increase job efficiency by sharing knowledge within organizations through implementation of Knowledge Map. Different from foregoing techniques, this research assumes that transferring tacit knowledge to explicit knowledge can be processed by using a Knowledge Map (Woo et al. 2004). Furthermore, the application of a Knowledge Map on a construction project can improve on attaining, capturing, sharing and reusing knowledge (Lin et al. 2006).

Developed in 1990s through research in field of education, the concept of Knowledge Map theory, is a technique of transferring text to structure which can display information of specific topic (O’Donnell 1993, 1994). Data is defined as simple observations, and information is defined as data with relevance and purpose (Davenport 1997). Users can identify connections and frameworks between information and data, and look for the required knowledge by using Knowledge Map. A Knowledge Map can show the distribution of webknowledge from search engine; besides, Knowledge Map displays who have particular knowledge in organization, also illustrates relationship between objects of knowledge (Dave and Koskela 2009; Gordon 2000; Lin and Hsueh 2006; Pyo 2005). 


\section{Knowledge Map}

Knowledge Map is a tool of knowledge management, which plays a significant role in knowledge management (Lin 2008; Lin et al. 2006). Knowledge Map can display employees' ability in an organization and their distribution of practical job experience. Moreover, it also can establish connections among documents (Srinivasan 1996; Xu and Ibrahim 2004; Yang and Luk 2003), increase teaching efficiency (O’Donnell 1993, 1994), help users to find out information in database more easily (Pyo 2005) and facilitate knowledge transfer (Meziane and Rezgui 2004). The potential application of a Knowledge Map is extensive, including law (Yang and Luk 2003), medical science (Srinivasan 1996), education (Lee and Tserng 2006; O’Donnell 1993, 1994), travel industry (Pyo 2005), information engineering (Yang and Luk 2003) and even civil engineering (Lee and Tserng 2004, 2006; Lin 2008; Tserng et al. 2009).

Current Knowledge Map related applications mainly focus on general industry of information retrieval and document classification. Only few specific industries have their particular Knowledge Map, for instance law (Yang and Luk 2003), medical science (Srinivasan 1996) and travel industry (Pyo 2005). There are many issues about KM, which been explored and discussed in related literature in construction industry. For instance, the precision and recall ability to automatic classify [Caldas et al. 2002], and the different relationships of index point to establish among documents in order to link up the connections (Hajjar and AbouRizk 2000). Connecting knowledge flow among jobsite and company, that via established knowledge management, and Explaining framework and application of dynamic Knowledge Map through concept description (Woo et al. 2004). Because the characteristic of different industry is very uniqueness, thus applying general knowledge map to construction industry is very difficult (Yin et al. 2005) except for literatures of project-base (Lin et al. 2006) and peoplebased knowledge map (Lin 2008). Current research was dealing with construction industry of Knowledge Map for classifying knowledge, storing knowledge (Yin et al. 2005), exchanging knowledge (Lin et al. 2006), capturing knowledge (Lin 2008), and reusing knowledge (Lee and Tserng 2004, 2006). However, the topic of knowledge reuse is not only an objective in the knowledge, but also a novel issue of existing literatures (Majchrzak et al. 2004; Tan et al. 2007). This research would focus on reusing knowledge, and enhance reusability of Knowledge Map in construction industry.

The objectives of this research were (1) to generalize existing mapping rules; (2) to develop a novel and practical model for building knowledge map; (3) to develop a system to improve reusability of Knowledge Map among practical process; (4) to validate Knowledge Map Model by real project in construction industry. To achieve the above objectives, this research conducted as following section. In Section 3, this research proposes a general mapping rules of knowledge map. In Section 4 and 5 will develop Knowledge Map Model (KMM) and Knowledge Map Model System. This research imple- mented KMM and KMMS in a real case in section 6, then presented and validated the application of KMM and KMMS in Section 7. Section 8 concludes this study (Fig. 1).

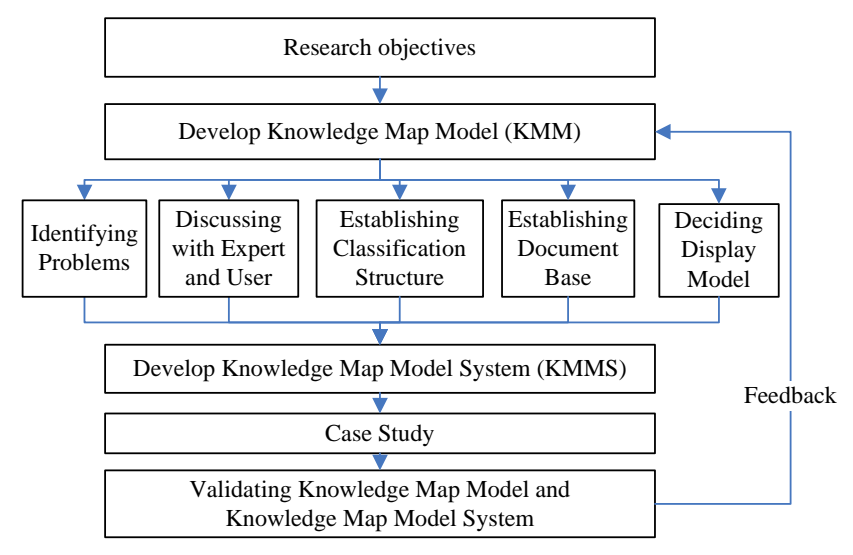

Fig. 1. The flow chart of this research

\section{Mapping Rules of Knowledge Map}

The mapping rule is the fundamental issue to establish Knowledge Map. Before to development a Knowledge Map Model for general and specific domain, this research generalized existing literatures, contain following six mapping rules. First rule, to discuss with Experts and Users, is manual approach to build knowledge map. This rule based on the experience of experts and uses, such as concept map and mind map, but it is not scalable of processing the large amounts of information (Ong et al. 2005). Classification Structure is the second rule for knowledge map (Pandit and Zhu 2007; Regui 2006), it contains too much information to apply to practical problems. Third, Document Base is essential resource for connecting knowledge, whose basic concept is to discover tacit relation in documents. The method of connecting knowledge named automatic text classifycation and clustering, which usually calculated by Text Mining and Information Retrieval (Lin et al. 2008, 2009; Ong et al. 2005). There are several commercial software to classify document, but without useful solutions for construction industry (Lin et al. 2006). However, this rule is necessary by controlling keyword and classifying result, but it is ineffective in specific domain.

Besides above-mentioned three independent mapping rules, they could also be combined two by two become three kinds of mapping rules. Fourth rule, Document Base combining with Classification Structure, which use classification structure on specific domain and assist automatic classified within document base. It is a useful approach to assist classified and suited on general domain. Fifth rule, Document Base combining with Experts and Users, which use document base to enhance the quantity of manual knowledge map (Lin 2008; Lin et al. 2006). Without fundamental classification structure, it will decrease reuse opportunity on knowledge map. Sixth rule, Classification Structure combining with Experts and Users (Pandit and Zhu 2007), that could assist user to develop a decision support system. Besides, Experts and 
Users could modify primary Classification Structure and decrease information overload. This rule is hard to update fresh documents for knowledge map. In order to improve existing mapping rules of knowledge map, which is not only apply to a general domain but also specific domain. This study generalized existing mapping rules, combined with mapping rules of discussing with Expert and User, Classification Structure, and Document Base for building knowledge map.

\section{Procedures of Implementing Knowledge Map}

From the literature review (Lee and Tserng 2004, 2006; Lin et al. 2006; Lin 2008), this research propose a novel and practical model named Knowledge Map Model (KMM) comprising five procedure identifying problem, discussing with experts and users, establishing classification structure, establishing document base, and deciding display model (Figs. 2 and 3).

\section{Procedure 1: Identifying Problems}

The first procedure in implementation of Knowledge Map is defining problems, which includes two major items: resolving questions via the Knowledge Map and ascertaining who the users of the Knowledge Map are.

Knowledge sharing, including learning and passing down experience usually happens during operating process of construction project, process of routine project in departments, and process of laboratory training (Cardoso Teixeira et al. 2006). Therefore, the first procedure in establishing map is understanding what problems needed to be solved, and designating problems between various departments within an enterprise, engineering project or technical crews.

After defining problems, cause of problems can be analyzed and method to solve the problems can be developed next. If there is a problem between the various departments in an enterprise, problems can be analyzed through an interview with managers of related departments.

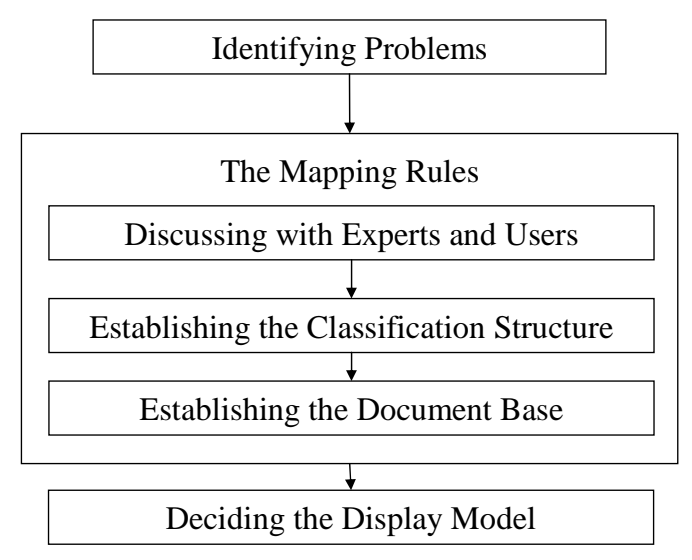

Fig. 2. Procedures of building Knowledge Map Model

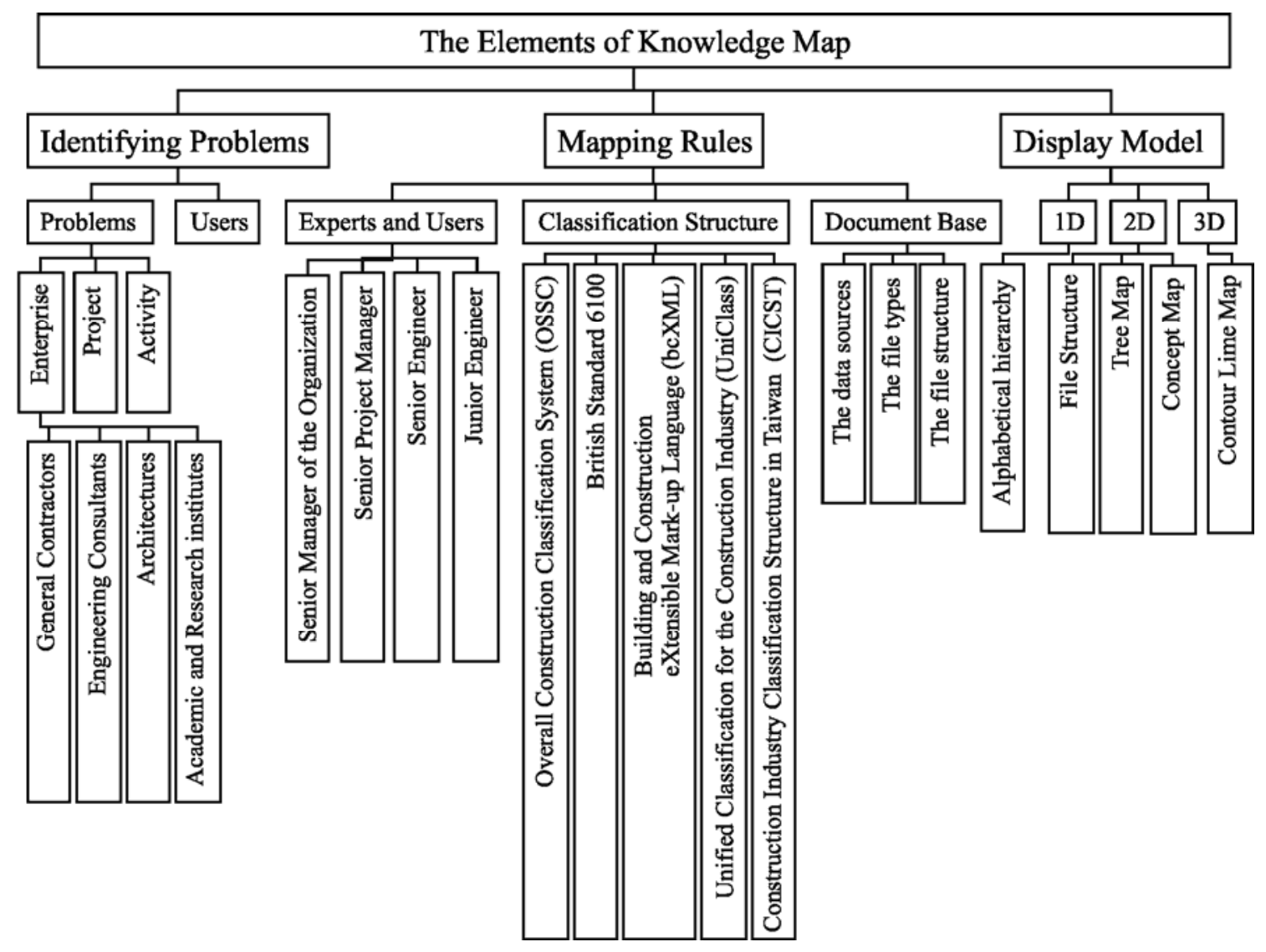

Fig. 3. The elements of Knowledge Map in construction industry 
If this is a problem happening in a construction project, besides asking for assistance from internal project managers, external experts can be consulted for their experienced input. If this is a problem occurring in technical crews, it would be better to employ experienced senior engineers. Because senior engineers can precisely identify problems that are tacit knowledge. Then, tacit knowledge could be transformed in to explicit knowledge through Knowledge Map. Therefore, next procedure is to discuss with experts and users.

\section{Procedure 2: Discussing with Experts and Users}

To discuss with experts and users is necessary procedure of building knowledge map. Experts could resolve users' problems, decide what knowledge for helping problem and translate tacit knowledge to explicit knowledge by manual knowledge map. Although the manual knowledge map could direct knowledge to the problem, but it's not easy to be shared and reused in different projects (Tan et al. 2007).

\section{Procedure 3: Establishing Classification Structure}

The third procedure is to establish a classification structure. Establishing classification structure is a standard framework for sharing with and reusing in different projects, which could assist to update and renew contents of knowledge map.

When establishing knowledge map of construction industry, significant references to classification structure contain Overall Construction Classification System (OSSC), British Standard 6100 (BS6100), Building and Construction eXtensible Mark-up Language (bcXML), Construction Industry Classification Structure in Taiwan (CICST) and Unified Classification for the Construction Industry (UniClass) (Caldas et al. 2002; Industrial Research Institute of National Taiwan University 2004; ElDiraby and Kashif 2005; Rezgui 2006). No matter what kinds of classification structures foundation will be, all classification structures established by every organization have to adjust by taking into account actual required tasks in order to solve users' real problems.

\section{Procedure 4: Establishing Document Base}

Document base is requiring useable resources when building Knowledge Map, which is critical content for supporting knowledge storage, share and update. In this procedure numerous and complicated documents are exploring tacit and systematic knowledge by manual and automatic document searching and retrieving (Lin et al. 2008, 2009; Ong et al. 2005). There are three principles to establish document base: data sources, file types, and file structures.

Data sources come from inside and outside organizations. Internal persons and departments provided data sources inside organization. The other organizations within the same trade, academic research institutions and internet provided data sources outside the organization.

File types include paper/book, electronic files and web-page files. Paper/book refers to the documents de- veloped before the advent of current computer technology. Due to tacit experience exist in documents is rarely and not easy to acquire, thus documents usually are required experts to classify and collect further. Moreover, tacit knowledge is decided when each document is read and analyzed manually. Electronic files and web-page files are researched chiefly applying information technology: for instance, Information Retrieval and Text Mining (Lin et al. 2008, 2009; Ong et al. 2005). No matter what kind of file models are, file content in construction industry contains primarily blueprints, design standards, design changes, scheduling, quality control reports (Caldas et al. 2002; Hajjar and AbouRizk 2000; Tserng and Lin 2004; Tserng et al. 2010).

File structure includes structured and unstructured documents. Structured documents mean makeup language in documents, such as eXtensible Mark-up Language (XML) documents. Unstructured documents mean documents composed by unstructured language. The connections between words are unknown, such as e-mail, web-page documents which words don't interpret metadata. Structured documents, which even permit access to tacit connections in documents, can usually be analyzed and explored by information retrieval technique. Unstructured documents have to be normally analyzed in different steps by use of labor-intensive manual textmining, semi-labor or semi-automatic phase which can determine the relationship between documents.

\section{Procedure 5: Deciding the Display Model}

To decide the display model is the fifth procedure for building Knowledge Map. The ways of display are respectively information visualization, to help users increase efficiency of judging connections between knowledge and attain required information easily by assistance of visualization. Display model of information visualization include File Structure, Tree Map, Concept Map and Mind Map, etc. The display types contain 1D, 2D, and 3D (Lee and Tserng 2006; Ong et al. 2005).

\section{Knowledge Map Model System}

Knowledge Map Model (KMM) is the practical model for implementing Knowledge Map to construction industry. Knowledge Map Model System (KMMS) is a tool for assisting KMM. Base on KMM, this research developed KMMS to provide user a re-useable knowledge map for representing the direction of explicit and tacit knowledge.

\section{System Architectures}

Knowledge Map Model System (KMMS) established within this research is a four-layer framework, including users' interface, acquisition of data, application of data, and database (Fig. 4). The layer of users' interface organizes interfaces of managers and end users. Users can utilize information via browsers, such as MS Internet Explorer and Mozilla Firefox and managers can set up different interfaces for different users. The layer of data acquisition provides the safety management, firewall and system management of internet. The layer of data 
application contains three major models, knowledge search engine, knowledge browsers and document base evaluator. That providing functions of display in Knowledge Map, document management, text retrieval and analysis of document connections, RSS, discussion communities, document recommendation and evaluation. The layer of database is established by My SQL, which includes user privileges, database of classification logic, database of classification structure, and database of document base.

Knowledge search engine, which searches knowledge documents established by the core of Knowledge Map, is designed for users to search for requiring documents by keywords. Knowledge browsers demonstrate classification structure defined in advance on system screen by display of knowledge tree, and sort documents by users' recommendations to permit users to know the most frequently consulted knowledge documents currently. Document Base Evaluator is mainly to provide feedback of users' behaviors of applying KMMS. It not only has functions of knowledge comments and discussion communities, but also records users' searching paths as one of the calculation bases of knowledge recommendation.
The first step to establish KMMS is to stipulate user's authorities in order to control functions of system utilized by different users. Authorities established at this research include system manager, users and browsers. System mangers can revise database of mapping rule, classification structure, document base and user authorities. Users can increase, revise, delete, comment and download knowledge document and discussion panel by the rules made by system managers. Browsers merely scan classification structure of knowledge or partial documents of knowledge. After establishing user's authorities, next step is to confirm classification logic for KMMS and document classification. This research adopts a vector space algorithm to classify documents automatically. Analysis of user behavior is based on document recommendations and reviewed frequency on documents. The next step is to establish a classification structure of Knowledge Map. Since this system intends to establish a Knowledge Map for specific domain, it is necessary to formulate classification structure of this domain as a base of automatic classification for supporting documents. The last step is to upload base knowledge documents by classification structure, and establishment of a rudimentary Knowledge.

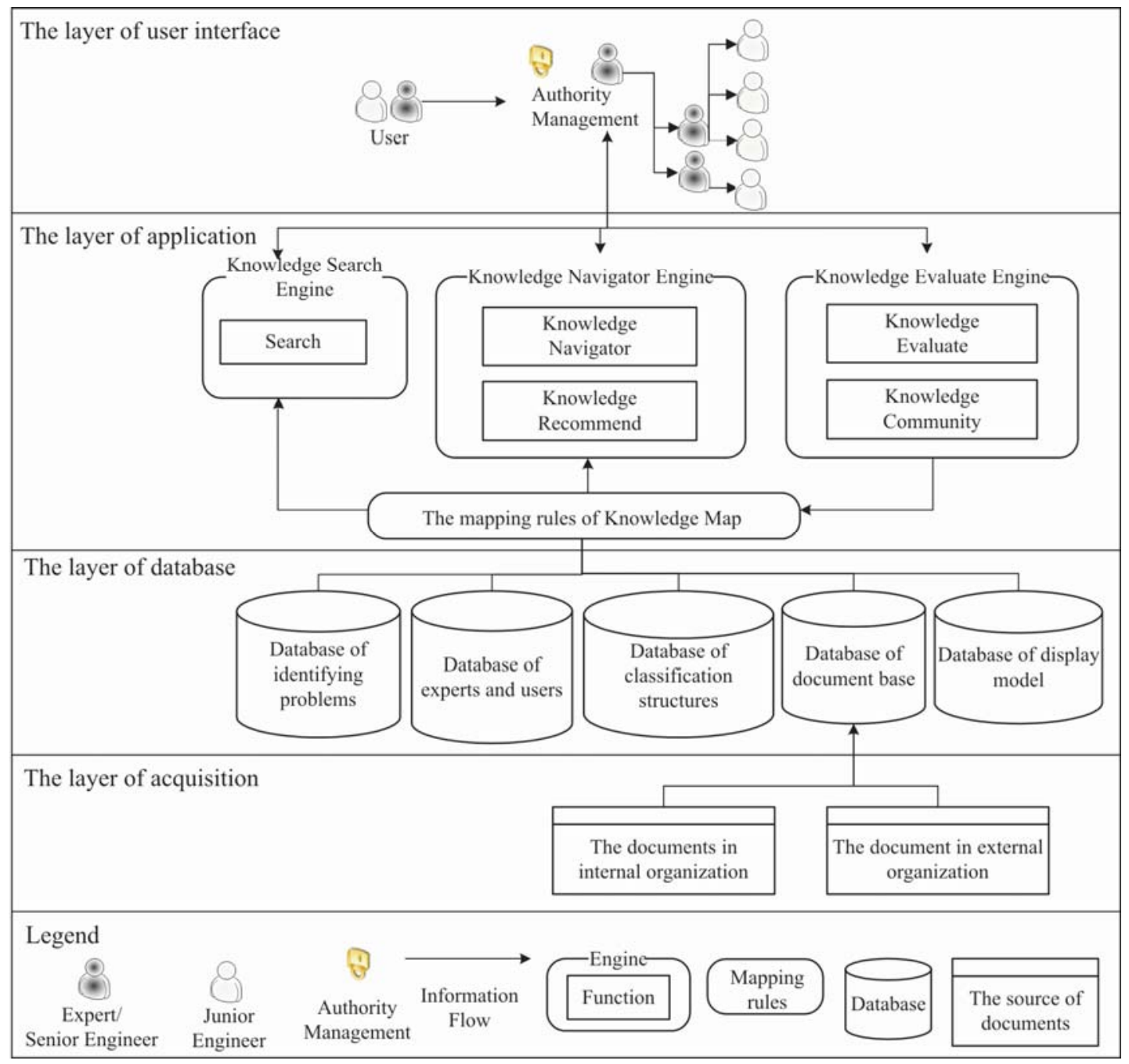

Fig. 4. The framework of the KMM system 


\section{Functions of KMMS}

There are six functions of the KMMS, which includes knowledge map, knowledge content, knowledge rating, related knowledge recommendation, knowledge discussion and knowledge classification recommendation.

1. Knowledge Map: Knowledge Map is the result of KMM and File Structure (Lee and Tserng 2004) is display model.

2. Knowledge Content: Knowledge Content describes profile of documents, releasing time and related attached files.

3. Knowledge Rating: Users conducts Knowledge Rating of documents, which one star point means low useful reference while five star points means high useful reference.

4. Related Knowledge Recommendation: Automatic method for Related Knowledge Recommendation uses Vector Space Model (VSM) and manual method uses users' suggestion (Ong et al. 2005).

5. Knowledge Discussion: In addition to knowledge rating, users can come up with other suggestions for document by text descriptions.

6. Knowledge Classification Recommendation: The other classify hierarchical documents are calculated automatically by system.

\section{Case Study}

Maintenance of bridge is an important social issue [0,0], although the decision support system could assist bridge maintenance projects, but it depends on correct input data from expects and senior (Xu and Ibrahim 2004). However, the numbers of experts and senior engineers are insufficient in the area of maintenance of bridge; for that reason, how to translate tacit experience to explicit knowledge becomes a major problem in bridge maintenance (Gattulli and Chiaramonte 2005; Miyamoto et al. 2000; Testa 2002; Wang and Elhag 2008).

In this research, the primary users, which is one of the engineering divisions of National Freeway Bureau in Taiwan is the real case to implement KMM and KMMS. This engineering division had ever built knowledge map for training junior engineering (Lee and Tserng 2006). This research would build knowledge map for bridge maintenance techniques. The case study included two workshops and four interviews.

A committee organized workshops that identify demands, problems, and classification structure of Knowledge Map in construction industry. The member in the committee includes fifteen members, they represented the chief of government officers, the CEO of construction industrial community, and professor of academic institutes (Industrial Research Institute of National Taiwan University 2004).

This research conducted the interviews with experts, such as government officers of Bridge Management Agency, private Construction Consultant Company, subcontractor of Bridge Maintenance Company, and academic institutes. The interviewees include three senior managers of bridge management agency (over 20 year practical experience in bridge management), three senior bridge maintenance engineers (over 10 year experience in bridge maintenance), five junior bridge maintenance engineers (1-3 year working experience), and two professors of construction management field (over 10 year researching experience).

Interviews indicate that senior bridge maintenance engineers have difficulty transferring knowledge to their junior colleagues. It requires knowledge map to support and acquire bridge maintenance techniques. With this information, the research established knowledge map for bridge maintenance techniques by KMM. Moreover, KMMS can become a platform of sharing and reusing knowledge and knowledge map. The interviews revealed that KMM is workable. Detailed process would explain in following articles.

\section{Procedure 1: Making Definitions of Problems}

It is understood after workshops and interviews that most of the professional techniques and construction experiences from senior engineers in organization of bridge maintenance management are tacit knowledge that cannot be learned and passed down efficiently. Junior engineers, who only know every procedure of bridge maintenance process and forms, documents, references in organization, cannot realize what kinds of connections between procedures and references in hands. Most of junior engineers learned connections by participating the projects to accumulate experiences but spent a lot of time. Regarding to new techniques of bridge maintenance devised by external organization, these junior engineers have no idea how to obtain this information besides using search engine.

\section{Procedure 2: Discuss with Experts and Users}

This research invited three senior managers, three senior engineers and five junior engineers of bridge maintenance and two professors in construction management to find out the solution. According to current situation of bridge maintenance, engineers generally need more learning opportunities besides the regular training courses to achieve the goal of learning and passing down knowledge. Training courses usually are informationoverloading and time-consuming (Lee and Tserng 2006; O’Donnell 1993, 1994). This research proposed to build a knowledge map for bridge maintenance to reduce information overloading and enhance knowledge map reusability for similar project of bridge maintenance.

Therefore, knowledge map could be implemented on KMMS which developed by this research. Hence, this research expects to simultaneously provide junior engineers more knowledge resources, and learning opportunities of passing down knowledge and sharing experience.

\section{Procedure 3: Establishing Classification Structure}

The third procedure is to devise reference classification structure. Since the methods of bridge maintenance are different because of different regulations in other countries, this research excluded related classification 
structures abroad, such as OCCS and UniClass (Industrial Research Institute of National Taiwan University 2004; Lin 2008; Rezgui 2006) and specifically took national framework as a reference. Furthermore, this research would compare classification structure CICST (Gordon 2000; Hajjar and AbouRizk 2000) promulgated by Industrial Research Institute of National Taiwan University in 2004. CICST has three major frameworks of construction industry: construction life cycle, construction techniques and construction application (Industrial Research Institute of National Taiwan University 2004).

This research built the bridge maintenance classification structure (Fig. 5) within real process for automatic classified and reference to the classification structure of CICST (Fig. 6).

\begin{tabular}{|l|l|}
\hline \multicolumn{2}{|c|}{ The classification structure of the bridge maintenance techniques } \\
\hline Superstructure \\
\hline Supporting Structure \\
\hline Sundation Structure \\
\hline Supplementary Facility \\
\hline Earthquake Stop/ Restrainer \\
\hline Approach Embankment \\
\hline Approach Guardrails \\
\hline Curb/ Sidewalk \\
\hline Sing/ Retaining wall \\
\hline Surface \\
\hline Drain Facilities \\
\hline Guard Rail \\
\hline Others \\
\hline
\end{tabular}

Fig. 5. The classification structure was building for bridge maintenance techniques

\section{Procedure 4: Establishment of Document Base}

Document base for bridge maintenance includes internal and external information. Internal information contains inspection evaluation reports, operating manuals, construction techniques of inspection and maintenance, and the know how of maintenance. External information comprises research report for construction techniques of inspection and maintenance, and investigation report of the international bridges.

\section{Procedure 5: Deciding the Display Model}

Since bridge maintenance knowledge map is based on the real process, the process was displayed on 2D space model, which is an expandable hierarchical in File Structure (Fig. 7). When user logs in to KMMS, the overall knowledge map always shows up, this is function of KMMS at the top of Fig. 7. Interface also provides the content of document, the rating score of knowledge, the suggested of related documents, the commented of knowledge, and the recommend of classification.

\section{Application of Knowledge Map}

The section will describe how engineers use knowledge map and how similar projects reuse knowledge map. Engineers can use "bridge maintenance knowledge map" among real process after finishing the KMM procedures. Based on Knowledge Map, the critical items of bridge maintenance can be specifically marked. Experts and senior engineers can respond the relevant problems on Knowledge Map. When junior engineers undertake a routine maintenance project, they could know an entire outline, a process of projects, and a framework of problems through Knowledge Map. Junior engineers could search for keyword in KMMS, and find out the solutions. Problems and solutions arise from the operation process should be reviewed and incorporated into Knowledge Map. If there is no existing knowledge map that can be utilized to handle the problem, senior engineers' could create and discuss new knowledge map for the problem on KMMS. In order to guarantee the quality of knowledge map, senior engineers would maintain KMMS every day in initial stage. Maintaining and updating frequency will reduce to once a month when junior engineers are familiar with KMMS.

After finishing the project of bridge maintenance, engineers could revise, update, analyze, and correct six functions of KMMS. The log in files and interactive information were recorded on KMMS, and that could provide solutions to similar problems when inquiry arises.

Furthermore, the primary users and other users who work in other divisions of National Freeway Bureau, the government office, and academic institutes, they can improve KMM and KMMS in the future by utilize KMMS, offering suggestions and feedbacks during the KMM procedures. Once the concepts of KMM be applied for different projects and organizations, which include owners, engineering consultants, architects, general constructors and academic institutes. Knowledge Map will be much easier to learn, experience will be much easier to pass down, and knowledge will be much easier to share. Other projects could reuse the elements of KMM, such as identify problems, classification structure and document base, and display model (Fig. 8). Through horizontal sharing of different projects within the same department, vertical sharing of the same project in different departments (Tserng and Chung 2007), and sharing of inter-project and inter-organization (Fig. 9), that precious experience can be preserved effectively to accumulating, preserving and distributing knowledge (Robertson and Reese 1999).

\section{Conclusion}

This paper presented a general knowledge map model that modifies existing mapping rules for general domain and for specific domain, a five-procedure for building a knowledge map, and a system to improve knowledge map. 


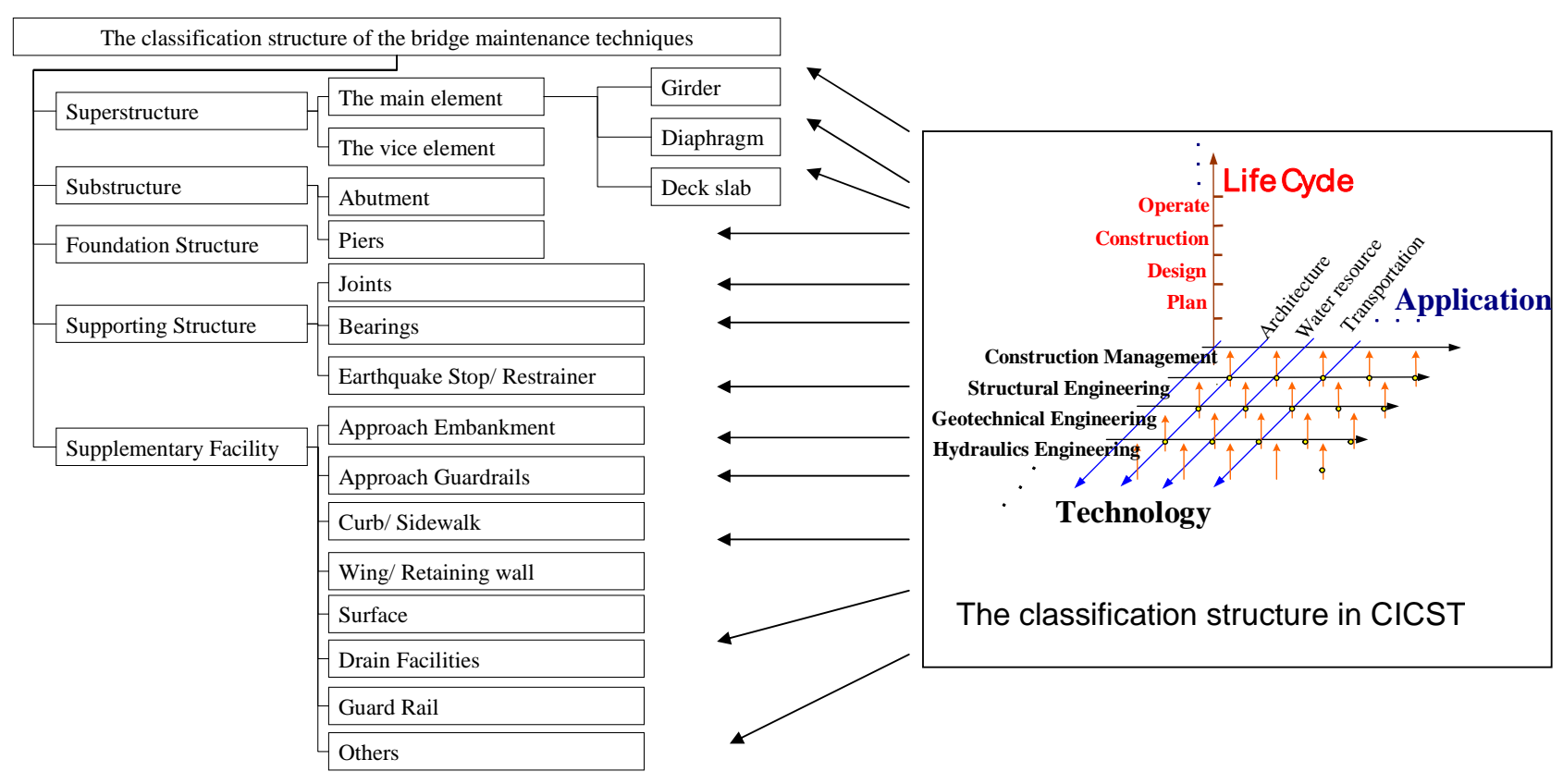

These arrows mean the reference of CICST.

The classification structure of the bridge maintenance techniques

The classification structure of CICST

1.Technology/1.4 structure engineering

/1.4.1structural mechanics

1.Technology/1.4structure engineering

1.4.2structural analysis

Superstructure

1.Technology/1.4structure engineering

1.4.4structural testing

1.Technology/1.4structure engineering

11.4.5structural design

1.Technology/1.4structure engineering

11.4.6the law of structural design

1.Technology/1.5geotechnical engineering

/1.5.1fundmental engineering

1.Technology/1.5geotechnical engineering

Superstructure

11.5.2retaining structure

1.Technology/1.5geotechnical engineering

11.5.4geoenvironmental engineering

1.Technology/1.5geotechnical engineering

/1.5.5monitoring technology

Fig. 6. The classification structure of bridge maintenance was reference of CICST 


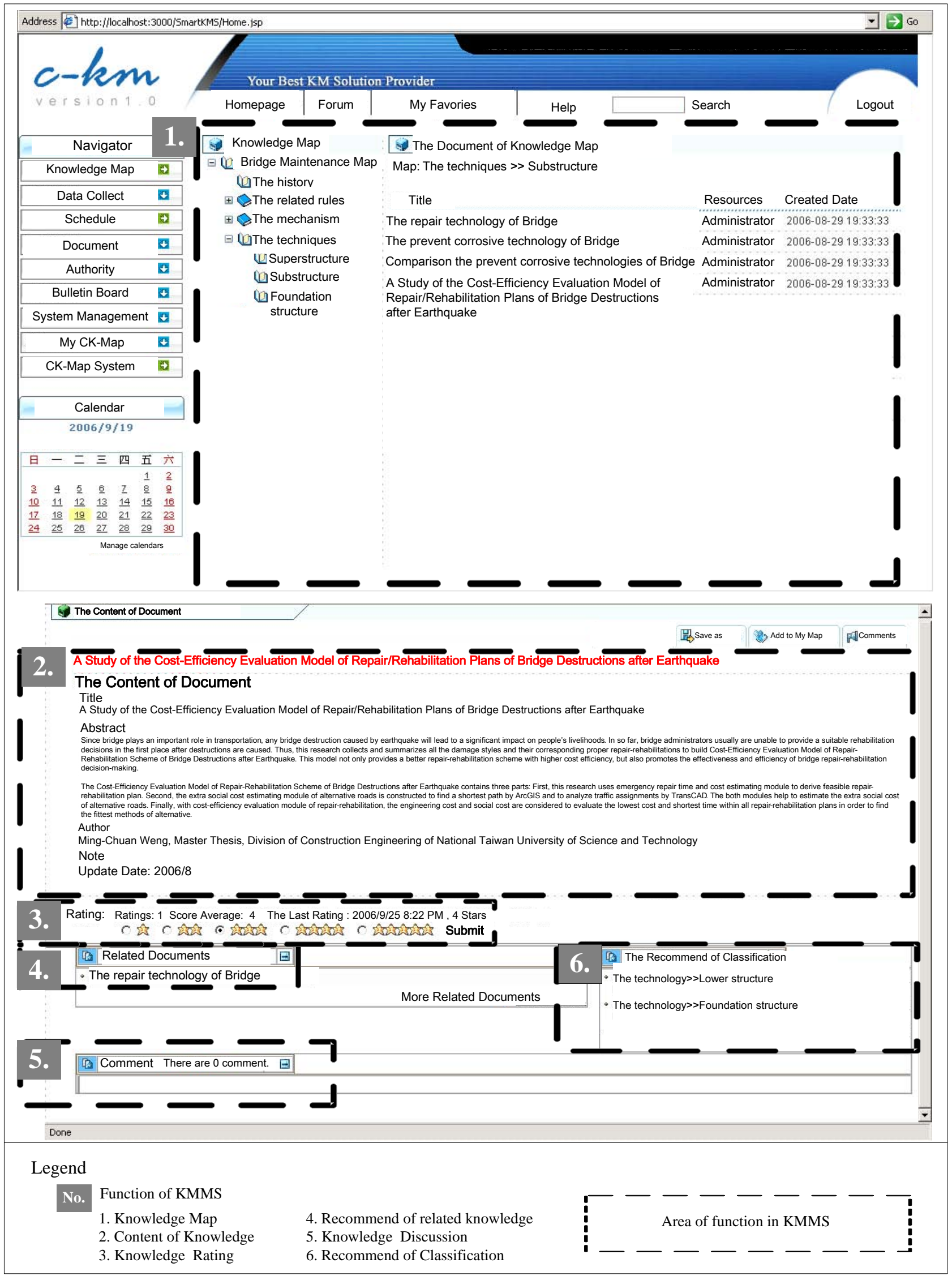

Fig. 7. The interface of Knowledge Map Model System 


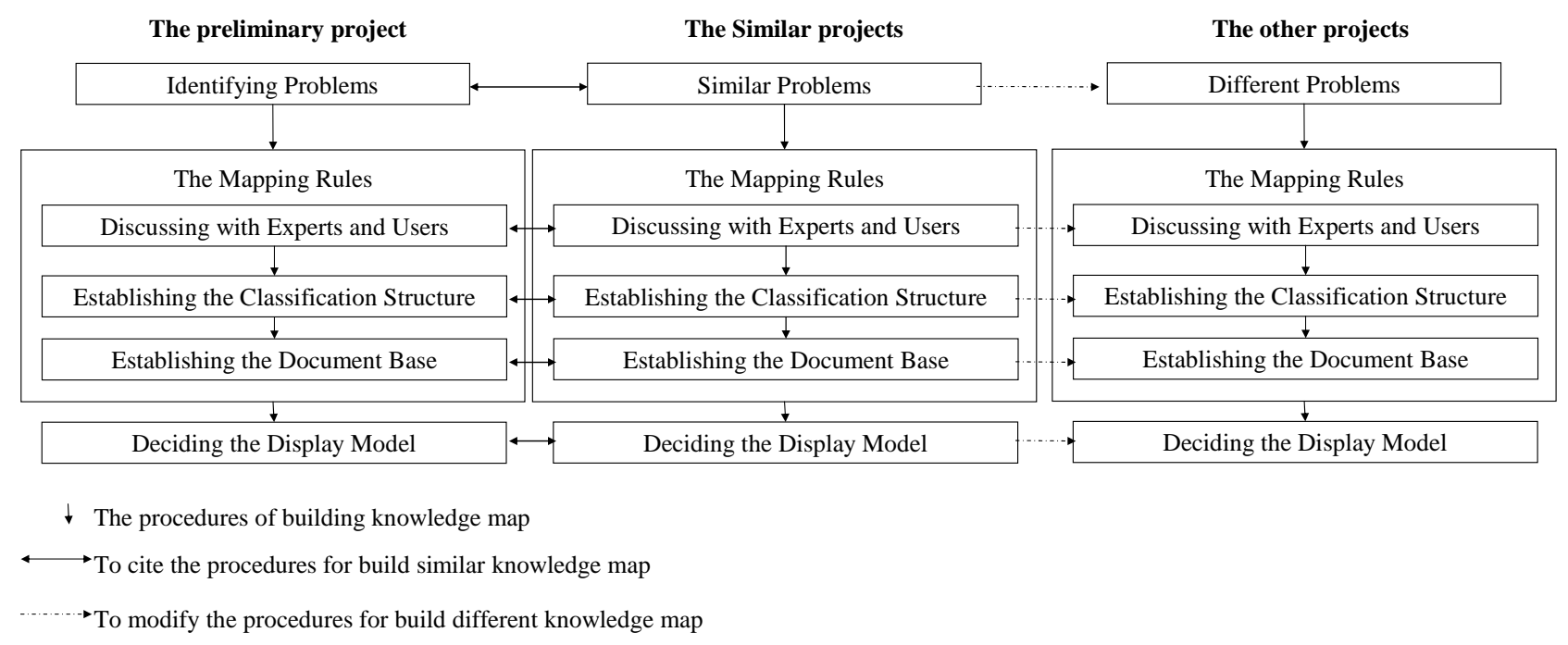

Fig. 8. The procedures and applications implement in Knowledge Map Model

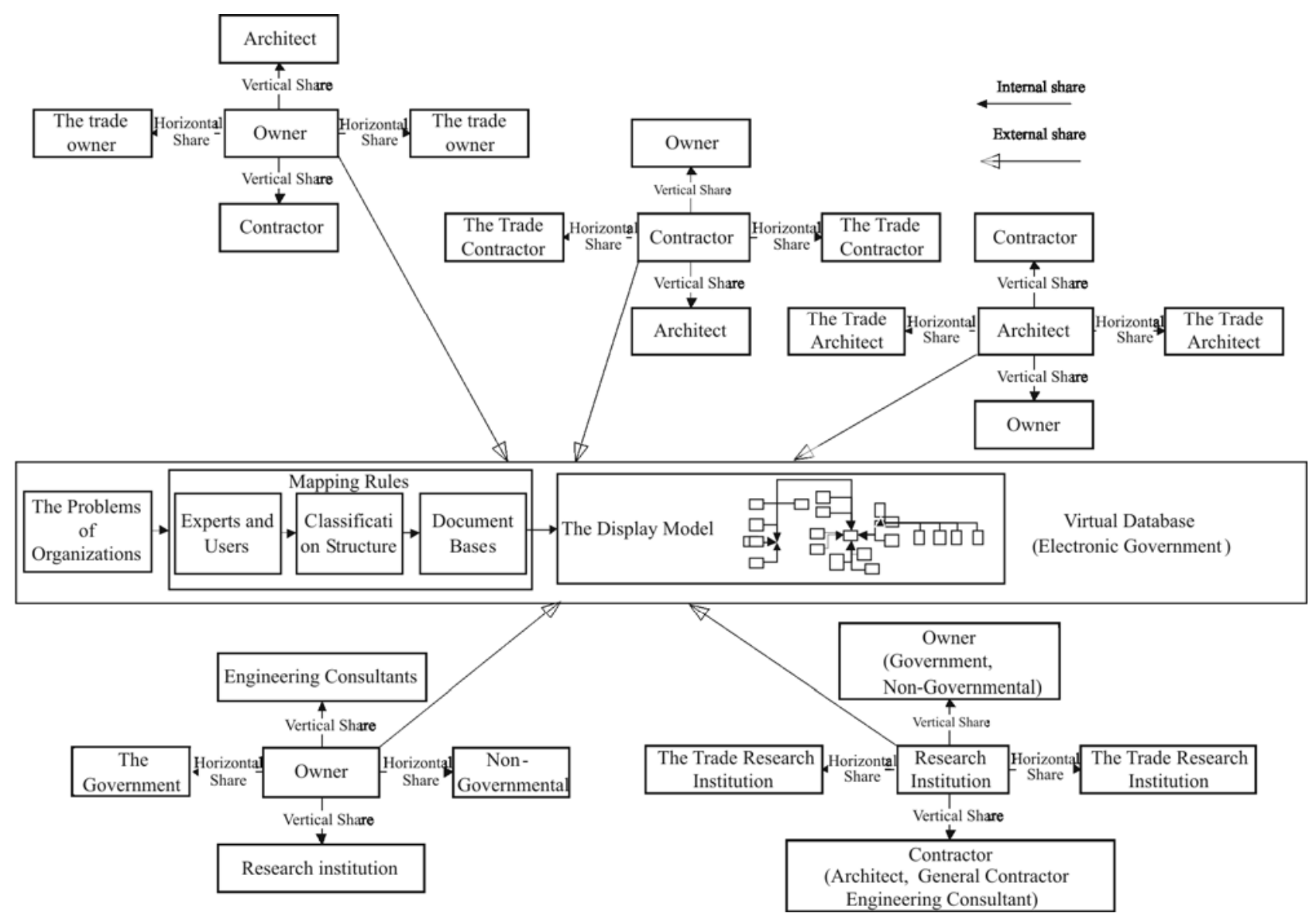

Fig. 9. The Knowledge Maps ruse and share in the different organization

Knowledge Map Model can not only apply to bridge maintenance project, as in the case study, but also other projects in the construction industry of Taiwan (Fig. 10). A case study on the application of this model verified the statement that KMM and KMMS effectively enhanced reusability of Knowledge Map among practical process within other organization.
However, experts and users gave the following feedback on the use of KMM. (1) This research validate KMMS is a helpful tool for reusing knowledge in the textual. However, the senior engineers indicate that input data of bridge maintenance also include numerical data and images (Tserng and Chung 2007). How to establish related knowledge in numerical data and images becomes 


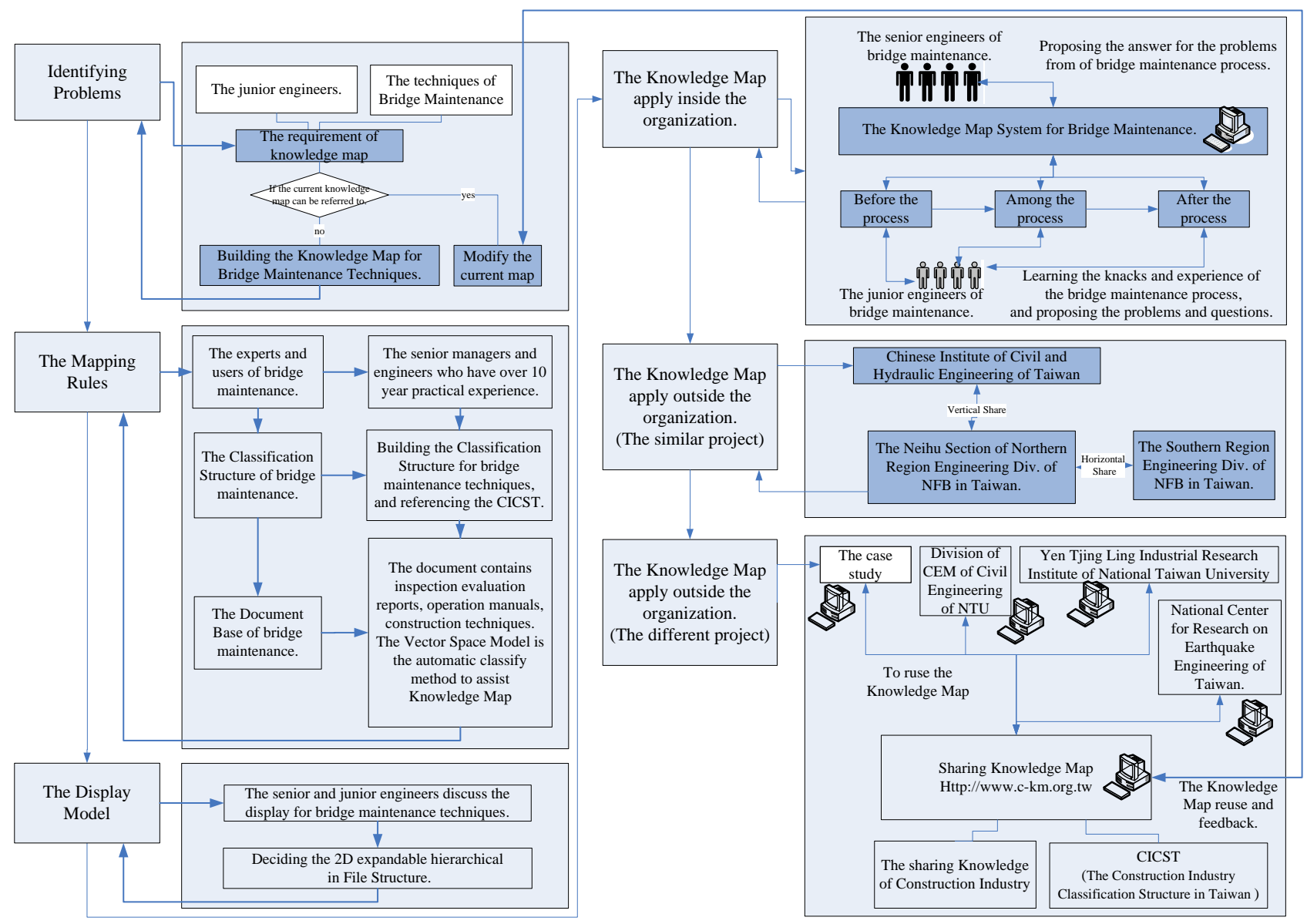

Fig. 10. The Knowledge Map Model applies to construction industry

another issue in the future. (2) In order to ensure the quality of knowledge map, senior engineer would become key person to maintenance KMMS. (3) The technology within mapping rule for document base is timeconsuming without the senior engineers who major in information technology, as well as bridge maintenance. (4) The knowledge rating is one of the motivation factors for improving user's participation in this research; moreover, how to encourage senior engineers' willingness of share experiences is an important issue in the strategy of KMM (Lin 2008).

Future research in construction industry should focus on building up new knowledge maps in specific topic for different demands. Constructing general ontology (Pandit and Zhu 2007; Rezgui 2006) to assist classification structure. Enhancing automatic classification algorithm (Caldas 2002) for numerical data and CAD files to extend document base. Developing multidimensional graphic user interface (Woo et al. 2004) to improve display model. Developing evaluation method to compare with different knowledge maps.

\section{References}

Caldas, C. H.; Soibelman, L.; Han, J. 2002. Automated classification of construction project documents, Journal of Computing in Civil Engineering 16(4): 234-243.

doi:10.1061/(ASCE)0887-3801(2002)16:4(234)
Cardoso Teixeira, J. M.; Minasowicz, A.; Zavadskas, E. K.; Ustinovichius, L.; Migilinskas, D.; Pellicer Armińana, E.; Nowak, P. O.; Grabiec, M. 2006. Training Needs in Construction Project Management: A Survey of 4 Countries of The Eu, Journal of Civil Engineering and Management 12(3): 237-245.

Dave, B.; Koskela, L. 2009. Collaborative knowledge management-A construction case study, Automation in Construction 18(7): 894-902.

doi:10.1016/j.autcon.2009.03.015

Davenport, T. H. 1997. Information Ecology. Oxford, University Press, New York, NY.

El-Diraby, T. E.; Kashif, K. F. 2005. Distributed ontology architecture for knowledge management in highway construction, Journal of Construction Engineering and Management 131(5): 591-603. doi:10.1061/(ASCE)0733-9364(2005)131:5(591)

Gabrielaitis, L.; Baušys, R. 2006. Electronic Document Management in Building Design, Journal of Civil Engineering and Management 12(2): 103-108.

Gattulli, V.; Chiaramonte, L. 2005. Condition Assessment by Visual Inspection for a Bridge Management System, Computer-Aided Civil and Infrastructure Engineering 20: 95-107. doi:10.1111/j.1467-8667.2005.00379.x

Gordon, J. L. 2000. Creating Knowledge Maps by exploiting dependent relationships, Knowledge-Based Systems 13(22): 71-79. doi:10.1016/S0950-7051(00)00048-4 
Hajjar, D.; AbouRizk, M. 2000. Integrating document management with project and company data, Journal of Computing in Civil Engineering 14(1): 70-77. doi:10.1061/(ASCE)0887-3801(2000)14:1(70)

Industrial Research Institute of National Taiwan University, 2004. Building the knowledge map classification structure and exchange standard of construction industry, The Final Report, Construction and planning agency of Ministry of the Interior, Reference in Chinese.

Lee, M. H.; Tserng, H. P. 2004. The Application of Knowledge Map in Construction Knowledge Management, in Proceeedings of 21st "International Symposium on Automation and Robotics in Construction (ISARC 2004)", Sep. 22-25, 2004, held Seju, Korea, 125-130.

Lee, M. H.; Tserng, H. P. 2006. The Knowledge Map Apply to Junior Engineer in Construction Industry, in Proceedings of 23rd "International Symposium on Automation and Robotics in Construction 2006 (ISARC 2006)" Oct. 3-5, 2006, Tokyo, Japan, 746-750.

Lin, F. R.; Hsueh, C. M. 2006. Knowledge Map Creation and Maintenance for virtual communities of practice, Information Process and Management 42(2): 551-568. doi:10.1016/j.ipm.2005.03.026

Lin, K. Y.; Chou, K. W.; Lin, H. T.; Hsieh, S. H.; Tserng, H. P. 2009. Exploring the Effectiveness of Chinese-to-English Machine Translation for CLIR Applications in Earthquake Engineering, Journal of Computing in Civil Engineering 23(3): 140-147.

doi:10.1061/(ASCE)0887-3801(2009)23:3(140)

Lin, K. Y.; Hsieh, S. H.; Tserng, H. P.; Chou, K. W.; Lin, H. T.; Huang, C. P.; Tzeng, K. F. 2008. Enabling the creation of domain-specific reference collections to support textbased information retrieval experiments in the architecture, engineering and construction industries, Advanced Engineering Informatics 22(3): 350-361. doi:10.1016/j.aei.2008.01.001

Lin, Y. C. 2008 Developing construction assistant experience management system using people-based maps, Automation in Construction 17(8): 975-982. doi:10.1016/j.autcon.2008.04.004

Lin, Y. C.; Wang, L. C.; Tserng, H. P. 2006. Enhancing knowledge exchange through web map-based knowledge management system in construction: Lessons learned in Taiwan, Automation in Construction 15(6): 693-705. doi:10.1016/j.autcon.2005.09.006

Majchrzak, A.; Cooper, L. P.; Neece, O. E. 2004. Knowledge Reuse for Innovation, Management Science 50(2): 174188. doi:10.1287/mnsc.1030.0116

Meziane, F.; Rezgui, Y. 2004. A document management methodology based on similarity contents, Information Sciences 158(1): 15-36. doi:10.1016/j.ins.2003.08.009

Miyamoto, A.; Kawamura, K.; Nakamura, H. 2000. Bridge Management System and Maintenance Optimization for Existing Bridges, Computer-Aided Civil and Infrastructure Engineering 15(1): 45-55. doi:10.1111/0885-9507.00170

O'Donnell, A. M. 1993. Searching for information in Knowledge Maps and texts, Contemporary Educational Psychology 18: 222-239. doi:10.1006/ceps.1993.1018

O'Donnell, A. M. 1994. Learning from Knowledge Maps: the effects of map orientation, Contemporary Educational Psychology 19(1): 33-44. doi:10.1006/ceps.1994.1004
Ong, T. H.; Chen, H.; Sung, W. K.; Zhu, B. 2005. Newsmap: a Knowledge Map for online news, Decision Support Systems 39(4): 583-597. doi:10.1016/j.dss.2004.03.008

Pandit, A.; Zhu, Y. 2007. An ontology-based approach to support decision-making for the design of ETO (EngineerTo-Order) products, Automation in Construction 16: 759770. doi:10.1016/j.autcon.2007.02.003

Pyo, S. 2005. Knowledge Map for tourist destinations - needs and implications, Tourism Management 26(44): 583-594. doi:10.1016/j.tourman.2004.03.001

Rezgui, Y. 2006. Ontology-centered knowledge management using information retrieval techniques, Journal of Computing in Civil Engineering 20(4): 261-270. doi:10.1061/(ASCE)0887-3801(2006)20:4(261)

Robertson, S.; Reese, K. 1999. A virtual library for building community and sharing knowledge, Int. J. HumanComputer Studies 51(3): 663-685. doi:10.1006/ijhc.1999.0277

Srinivasan, P. 1996. Optimal document-indexing vocabulary for MEDLINE, Information Processing and Management 32(5): 503-514. doi:10.1016/0306-4573(96)00025-8

Tan, H. C.; Carrillo, P. M.; Anumba, C. J.; Bouchlaghem, N. D.; Kamara, J. M.; Udeaja, C. E. 2007. Development of a methodology for live capture and reuse of project knowledge in construction, Journal of Management in Engineering 23(1): 18-26. doi:10.1061/(ASCE)0742-597X(2007)23:1(18)

Testa, R. B. 2002. Bridge maintenance level assessment, Computer-Aided Civil and Infrastructure Engineering 17: 358-367. doi:10.1111/1467-8667.00282

Tserng, H. P.; Chung, C. L. 2007. Health assessment and maintenance strategy for bridge management systems: lessons learned in Taiwan, Journal of Infrastructure Systems 13(3): 235-246. doi:10.1061/(ASCE)1076-0342(2007)13:3(235)

Tserng, H. P.; Lin, Y. C. 2004. Developing an activity-based knowledge management system for contractors, Automation in Construction 13(6): 781-802. doi:10.1016/j.autcon.2004.05.003

Tserng, H. P.; Yin, S. Y. L.; Dzeng, R.J.; Wou, B.; Tsai, M. D.; Chen, W.Y. 2009. A study of ontology-based risk management framework of construction projects through project life cycle, Automation in Construction 18(7): 9941008. doi:10.1016/j.autcon.2009.05.005

Tserng, H. P.; Yin, S. Y. L.; Skibniewski, M. J.; Lee, M. H. 2010. Developing an ARIS-house-based method from existing information systems to project-based enterprise resource planning for general contractor, Journal of Construction Engineering and Management 136(2): 199-209. doi:10.1061/(ASCE)CO.1943-7862.0000125

Wang, Y. M.; Elhag, T. M. S. 2008. Evidential reasoning approach for bridge condition assessment, Expert Systems with Applications 34: 689-699. doi:10.1016/j.eswa.2006.10.006

Woo, J. H.; Clayton, M. J.; Johnson,R. E.; Flores,B. E.; Ellis, C. 2004. Dynamic Knowledge Map: reusing experts' tacit knowledge in the AEC industry, Automation in Construction 13(2): 203- 207. doi:10.1016/j.autcon.2003.09.003

Xu, C. Z.; Ibrahim, T. I. 2004. A keyword-based semantic prefetching approach in internet news services, IEEE Transactions on Knowledge and Data Engineering 16(5): 601611. doi:10.1109/TKDE.2004.1277820 
Yang, C. C.; Luk, J. 2003. Automatic generation of English/Chinese thesaurus based on a parallel corpus in laws, Journal of the American Society for Information Science and Technology 54(7): 671-682. doi:10.1002/asi.10259
Yin, S. Y. L.; Tserng, H. P.; Tsai, M. D. 2005. A model of integrating the cycle of construction knowledge flows: Lessons learned in Taiwan, Automation in Construction 17(5): 536-549. doi:10.1016/j.autcon.2007.10.002

\section{ŽINIŲ ŽEMĖLAPIO MODELIO NAUDOJIMAS STATYBOS PRAMONĖJE}

\section{H. Ping Tserng, Samuel Yen-Liang Yin, Meng-Hsueh Lee}

\section{S a n tra k a}

Statybos pramonėje taikoma daug nestruktūrizuotų dokumentu̧, kuriuose sukaupti tiksliai neišreikšti, numanomi duomenys. Bendruoju atveju žinių žemėlapis gali parodyti žinių tarpusavio ryšius ir transformuoti numanomas žinias į tikslias žinias, tačiau tai netinka specifinèms sritims, tokioms kaip statyba. Šis mokslinis tyrimas apibendrino esamas žinių žemèlapių sudarymo taisykles, kurios galètų būti taikomos bendrosioms ir specifinėms sritims, ir pristatė naują praktinį žinių žemėlapio sudarymo modeli, pavadintą KMM (Knowledge Map Model). Modeli sudaro penkios procedūros: problemu identifikavimo, aptarimo su ekspertais ir vartotojais, klasifikavimo struktūros nustatymo, dokumento formos nustatymo ir sprendimo dèl vaizdinio parinkimo. Be to, šiais moksliniais tyrimais nustatyta, kad žiniǔ žemėlapio modelio sistema (KMMS) yra svarbi priemonè, padedanti pritaikyti žinių žemėlapio naudojimą praktiniams tikslams. Galiausiai šis tyrimas pagrindè KMM taikymą vykdant realų tilto eksploatacijos projektą.

Reikšminiai žodžiai: žinių žemėlapis, statybos pramonè, informacinės technologijos.

H. Ping TSERNG is a full professor at the Department of Civil Engineering of National Taiwan University. He also is corresponding member of Russian Academy of Engineering. He has a $\mathrm{PhD}$ in Construction Engineering and Management and he is official reviewer or editorial board member of several international journals. His research interests include advanced techniques for knowledge management, management information system, GPS/Wireless Sensor Network, and automation in construction.

Samuel Yen-Liang YIN is CEO and Chief R\&D Officer of Ruentex Group as well as a professor at the Department of Civil Engineering of National Taiwan University. He also is the member of Russian Academy of Engineering. He has a $\mathrm{PhD}$ in Business Management. He received ASCE Henry. L. \& Michel Award (2010) and Engineering Glory Award by Russian Academy of Engineering (2008). His research interests include advanced techniques for pre-cast construction method, management information system, and automation in construction.

Meng-Hsueh LEE got PhD degree from the Department of Civil Engineering of National Taiwan University in Oct. 2009. He has joined several research projects funded by National Science Council of Taiwan. His research interests include knowledge management, knowledge map, information retrieval and enterprise resource planning. 